\title{
Pyricularia grisea: novo patógeno em Brachiaria brizantha cv. Marandu no Pará
}

\author{
Jaqueline Rosemeire Verzignassi ${ }^{1}$; Luiz Sebastião Poltronieri ${ }^{2}$; Ruth Linda Benchimol ${ }^{2}$; Sueny Kelly Santos de \\ França²; Eudes de Arruda Carvalho ${ }^{2}$; Celso Dornelas Fernandes ${ }^{1}$
}

\begin{abstract}
${ }^{1}$ Embrapa Gado de Corte, Avenida Rádio Maia, 830, CEP 79106-550, Campo Grande, MS. ²Embrapa Amazônia Oriental, Tv. Enéas Pinheiro, S/ N, CEP 66095-100, Belém, PA.

Autor para correspondência: Jaqueline Rosemeire Verzignassi (jaqueline@cnpgc.embrapa.br)

Data de chegada: 02/07/2012. Aceito para publicação em: 23/07/2012.
\end{abstract}

O brizantão, braquiarão ou capim-marandu (Brachiaria brizantha cv. Marandu) é uma gramínea de rápido estabelecimento, boa produtividade, resistência às cigarrinhas típicas de pastagem e alta produção de sementes, além de apresentar boa adaptação a diferentes condições edafoclimáticas. Esses atributos proporcionaram a essa forrageira alta aceitação pelos criadores de gado, refletida pela extensa área cultivada, de cerca de 60 milhões de hectares em todo o território nacional, sendo a forrageira mais representativa da região amazônica. Sua participação no mercado de sementes de forrageiras vem crescendo desde o seu lançamento, em 1983, representando, atualmente, $90 \%$ do volume de sementes de forrageiras comercializado no Brasil. No entanto, o ataque de fitopatógenos como Pythium perillum, Rhizoctonia solani e Fusarium sp., aliado a outros fatores como estresses hídrico e nutricional e manejo deficitário, tem contribuído com a síndrome da morte de pastagens de braquiarão em diversas regiões do país. Recentemente, em áreas de braquiarão em Rondon do Pará (PA) e no Estado do Maranhão, observou-se mortalidade de 80 a $90 \%$ das plantas. Folhas de plantas, com idade aproximada de 60 dias, coletadas nas duas localidades, apresentavam pontuações castanhoavermelhadas (Figura 1A), que evoluíam para manchas elípticas de até $2 \mathrm{~cm}$ de comprimento por $0,5 \mathrm{~cm}$ de largura (Figura 1B). As lesões individuais coalesciam, formando extensas áreas necrosadas (Figura 1B), com queima total das folhas. O patógeno isolado dos tecidos infectados foi Pyricularia grisea (Cooke) Sacc., que ocorre em mais de 50 gramíneas, entre elas o arroz (Oryza sativa) e o trigo (Triticum aestivum). O referido isolado foi inoculado $\left(10^{6}\right.$ conídios. $\mathrm{mL}^{-1}$ ) em plantas sadias com 30 dias de idade, submetidas à câmara úmida $\left(80 \% \mathrm{UR} ; 30^{\circ} \mathrm{C}\right)$, e os sintomas foram reproduzidos oito dias após a inoculação. P. grisea foi também detectada em $8 \%$ das sementes de amostra de um lote utilizado para o plantio em Rondon do Pará. Este é o primeiro relato da ocorrência de $P$. grisea em braquiarão na Amazônia.

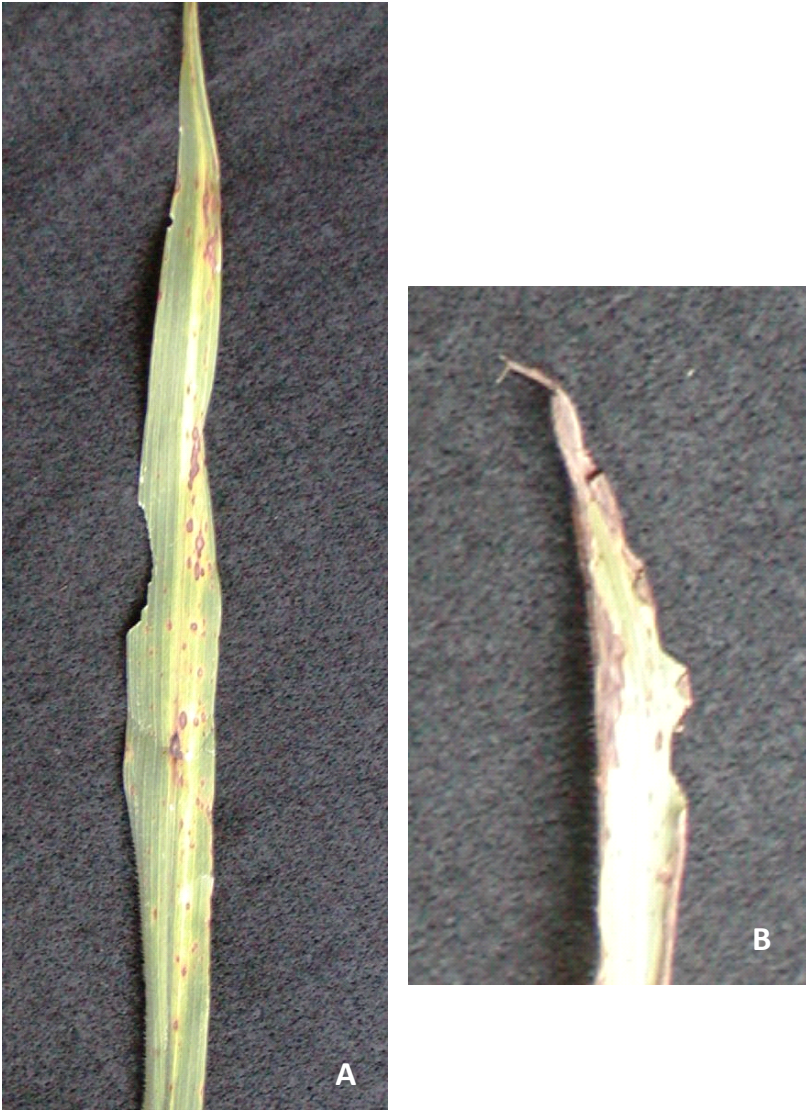

Figura 1. Queima da Brachiaria brizantha cv. Marandu causada por Pyricularia grisea: sintomas iniciais da doença (A) e folha com sintomas avançados, com aspecto de queima (B). 